\title{
НЕІНВАЗИВНЕ ВИМІРЮВАННЯ ПАРАМЕТРІВ ГЕМОДИНАМІКИ МІКРОЦИРКУЛЯТОРНОӦ ЛАНКИ СИСТЕМИ КРОВООБІГУ
}

\author{
Інститут кібернетики ім. В. М. Глушкова НАН України
}

\section{B. I. Дегтярук}

Описаны способ и устройство для неинвазивного измерения параметров гемодинамики микроциркуляторного отдела системы кровообращения, основанный на фотометрическом методе.

Пропонований підхід базується на явищі поглинання світла молекулами гемоглобіну. Спектральна інтенсивність I світла, що пройшла крізь шар розчину товщиною $d$, описується формулою, яка базується на законі Бугера-Ламберта-Бера:

$I=T I_{0} \exp (-k d)$

де $I_{0}$ - спектральна інтенсивність світла на вході в розчин;

$k$ - коефіцієнт поглинання світла в розчині;

$T$ - коефіцієнт пропускання кювети з прозорим розчином.

Якщо розчин включає один барвник:

$K=k_{\text {mol }} c$,

де $k_{\text {mol }}$ - молярний коефіцієнт поглинання барвника;

$c$-його молярна концентрація.

Вимірюючи спектральні інтенсивності $I_{0}$ та I в смузі поглинання барвника, пропускання кювети $T$ та знаючи $k_{\text {mol }}$ та $d$ за формулами $(1,2)$ можна обчислити концентрацію барвника.

При проходженні світла крізь живу тканину воно послаблюється не лише через поглинання, а й в результаті розсіювання. Тому замість формули (2) маємо

$K=K_{p}+k_{\text {mol }} c$,

де $K_{p}$ - коефіцієнт послаблення, зумовлений розсіюванням світла.

Авторами вибрана двохвильова схема вимірювань «на відбивання» де в якості інформаційного параметра використовують зворотно розсіяне світло.

Спектральні інтенсивності світла, яке виходить 3 тіла, описуються рівняннями

$I_{O}=T_{O} I_{R, O} \exp \left[-\left(K_{p, O}+K_{B, O}+k_{h b, O} c_{h b}\right) d\right]$

$I_{B}=T_{B} I_{B, O} \exp \left[-\left(K_{p, B}+K_{B, B}+k_{h b, B} c_{h b}\right) d\right]$

Індекси «О» та «В» вказують на опорну $1_{O}$ та вимірювальну довжину хвилі $1_{B}$.

$I_{R, O}, I_{B, O}-$ спектральні інтенсивності світла на вході в тканину.

$T_{O}, T_{B}$ - коефіцієнти пропускання світла тканиною; $K_{p, O}, K_{p, B}-$ коефіцієнти розсіювання, задаються в $\mathbf{M}^{-1}$;

(В. I. Дегтярук
$k_{B, O}, k_{B, B}-$ коефіцієнти поглинання світла компонентами тканини, задаються в $\mathrm{M}^{-1}$;

$k_{h b, O}, k_{h b B}-$ молярні коефіцієнти поглинання світла гемоглобіном, задаються в м²/моль;

$c_{h b}$ - молярна концентрація гемоглобіну, моль/ м $^{3}$;

$d$ - усереднена довжина шляху, який проходить у тканині світло, що потрапляє на фотоприймач, м.

Довжини хвиль $1_{O}, 1_{B}$ вибираються так, щоб розсіювання та фонове поглинання світла для них були майже однакові (тобто $K_{p, O} \gg K_{p, B}, k_{B, O} \gg k_{B, B}$ ), а молярні коефіцієнти поглинання гемоглобіном суттєво відрізнялись $\left(k_{h b, B}>>k_{h b, O}\right)$.

Один з варіантів обробки результатів вимірювання отримують, якщо вираз (4) поділити на вираз (5).

$\left.I_{O} / I_{B}=\left(T_{O}, I_{p, O} T_{B}, I_{B, O}\right) \exp \left[\left(k_{h b, B}-k_{h b, p}\right) c_{h b}\right) d\right]$

Вирішивши це рівняння відносно $c_{h b}$, отримаємо:

$c_{h b}=\left[\ln \left(I_{p} / I_{B}-\ln \left(T_{p,} I_{p, O} / T_{B}, I_{B, O}\right)\right] /\left[k_{h b, B}-k_{h b, p}\right) d\right]$

Величини $T_{p}, T_{B}, I_{p, O}, I_{B, O}$, та $-d$ константи приладу і визначаються конструкцією вимірювальної головки приладу та каналом обробки сигналів.

Таким чином, визначається усереднена концентрація гемоглобіну в тканині. Знаючи площу фотоприймача $S$ та довжину шляху $d$, який пройшло світло в тканині, можна вирахувати об' єм тканини, для якої визначається концентрація гемоглобіну:

$V=S d$

Знаючи об'єм тканини та концентрацію гемоглобіну визначається ії кровонаповнення:

$P=V \cdot c_{h b}$

Реалізація способу виконується за допомогою приладу «Гемодин», розробленого в інституті кібернетики ім. В. М. Глушкова НАН України.

Дослідження проводиться на дистальних фалангах пальців. Вибір місця дослідження зумовлений тим що найменші порушення кровообігу мікроциркуляторної ланки насамперед відбуваються в периферійних ділянках тіла людини. Зовнішній вигляд приладу представлено на рисунку 1.

Принцип дослідження пояснюють рисунки 1, 2. Пацієнт займає на сидінні зручне положення. Руку, 


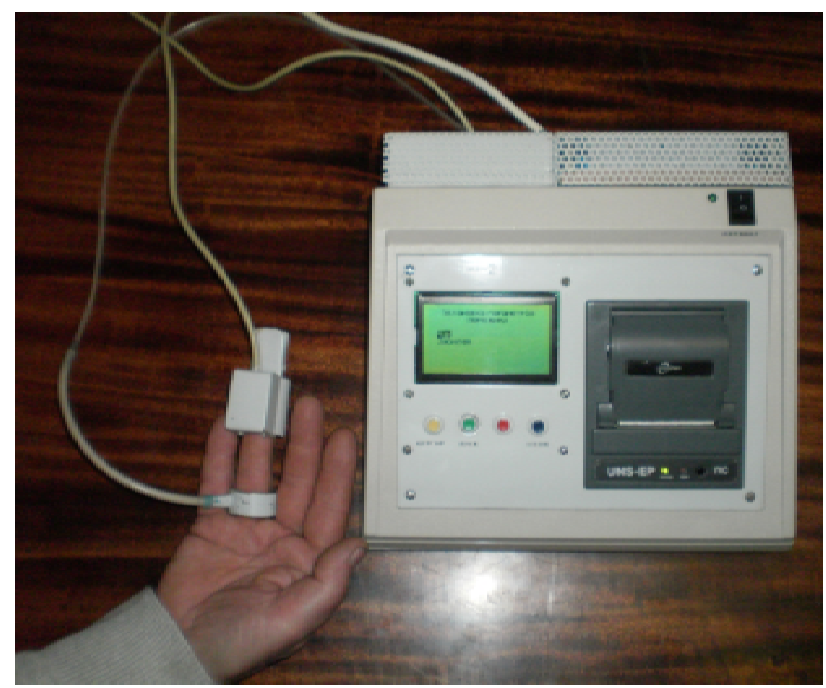

Puc. 2. Зовнішній вигляд приладу для вимірювання параметрів гемодинаміки.

на якій виконують вимірювання, розташовують в розслабленому стані на лабораторному столі.

На основу пальця одягають компресійну манжету, виконану у вигляді кільця. Величину тиску $P_{x}$ лікар вибирає за допомогою меню в залежності від артеріального тиску пацієнта та мети досліджень На дистальну фалангу пальця одягаються вимірювальну головку, виконану у вигляді слабо напруженої кліпси. Після завершення підготовчих операцій з клавіатури подається команда «пуск» і починається процес вимірювання.

Після закінчення операції балансування включається мікрокомпресор і тиск в манжеті підвищується до заданого значення, яке вище діастолічного $P_{c}$. Цей тиск передається на всі кровоносні судини під манжетою. Коли тиск стає вищим за тиск у венах, відтік крові припиняється, а кровонаповнення пальця 3 моменту $t_{0}$ зростає. Інтервал перетискання задається лікарем і також визначається метою досліджень.

Результати вимірювання відображаються на рідкокристалічному екрані в реальному масштабі часу у вигляді графіка. Швидкість наростання сигналу пропорційна ctga, або кількості притоку крові до пальця, отже може бути характеристикою величини об'ємного кровотоку в пальці.

Оскільки тиск в манжеті фіксований, то максимальне значення сигналу $A_{M}$ тим більше, чим вища еластичність кровоносних судин пальця.

Кількісна характеристика еластичності кровоносних судин називається компліансом. Вимірюють його в л/Па.

Трансмуральний тиск всередині судин під дією пережиму досягає величини $P_{M}$. Зовнішній атмосферний тиск залишається незмінним, його значення прий-

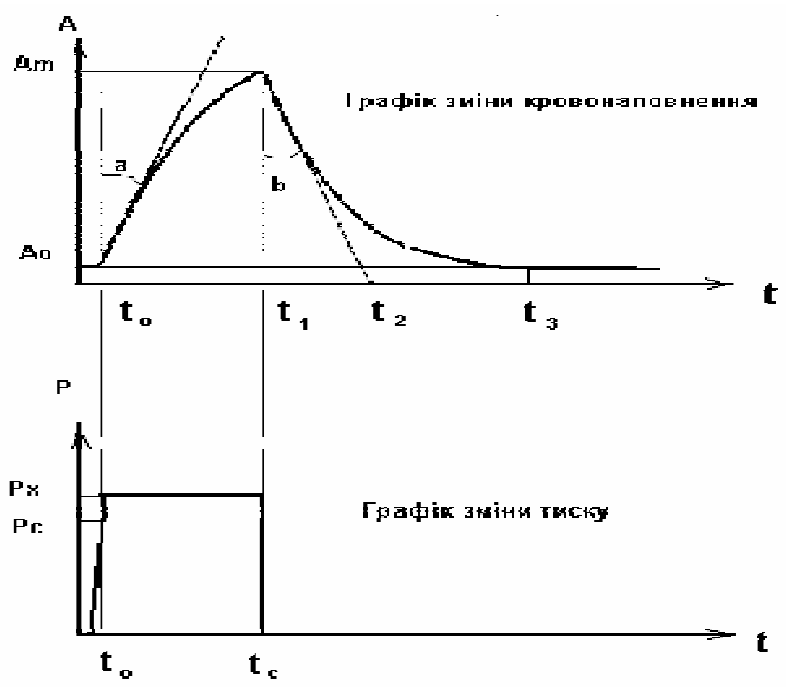

Puc. 3. Графік зміни кровонаповнення та тиску.

мається за нуль. Об'єм крові в мікроциркуляторному руслі зростає на величину:

$\mathrm{D} V=\mathrm{Ce} \cdot \bullet P_{\mu^{\prime}}$

де $C$ - сумарний компліанс судин на досліджуваній ділянці тіла, кровонаповнення якої зростає на величину $\mathrm{D} k=\mathrm{D} V / V \cdot 100 \%$,

де $V$ - об'єм досліджуваної ділянки тіла.

Враховуючи вирази $(10,11)$ можна розрахувати питомий компліанс судин мікроциркуляторного русла: $P=V \cdot c_{h b}$

В шкірі та тканині пальців капілярна сітка не дуже

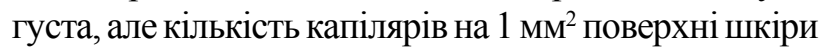
в нігтьовому ложі від 20 до 55, на зворотній поверхні долоні - до 65. До кожного шкірного сосочка підходить 3-4 капіляри, які утворюють петлі завдовжки 200-400 мкм. Артеріальна частина петлі має діаметр 7-13 мкм, а венозна 9-20 мкм.

Площа чутливого елемента фотоприймача кілька мм² $^{2}$. Так, фотоприймачі ОРТ-101,ОРТ-301 фірми BURR-BROWN Corporation, які використовували автори, мають площу 5,2 мм². Отже, інформація сприймається більше ніж від 300 капілярів і стількох посткапілярних венул.

Після закінчення інтервалу перетискання $\mathrm{t}_{1}$ кровонаповнення досягає рівня $A_{M}$, спрацьовує декомпресійний клапан і тиск у манжеті падає до нуля. Починається процес відновлення кровообігу. Кровонаповнення пальця починає зменшуватись. Початкова швидкість зменшення сигналу залежить від гідравлічного опору судин відтокові крові:

$d k / d t=\mathrm{D} A /(C \cdot R)$,

де $\mathrm{D} A=A_{M}-A_{0}-$ амплітуда зміни кровонаповнення, $R$ - питомий гідравлічний опір судин відтоку крові. 
Висновки. Динаміка зміни кровонаповнення на низхідній ділянці характеристики дозволяє визначати питомий гідравлічний опір мікросудин відтокові крові, тобто венозної частини. Відповідно визначається гідравлічний опір артеріальної частини мікросудин притокові крові після перетискання, тобто на

\section{Література}

1. Чернух А. М. Микроциркуляция / А. М. Чернух, П. Н. Александров, О. В. Алексеев. - М. : Медицина, 1984. $-432 \mathrm{c}$.

2. Патент на винахід № 98366 Спосіб неінвазивного визна- висхідній ділянці графіка. Момент часу $\mathrm{t}_{3}$ визначає повернення досліджуваної ділянки мікроциркуляторної ланки системи кровообігу до вихідного стану, а інтервал $\mathrm{t}_{3}-\mathrm{t}_{1}$-час відновлення кровообігу $\mathrm{i}$ характеризує ефективність регуляторних механізмів.

чення параметрів гемодинаміки системи кровообігу / Войтович І. Д., Дегтярук В. І., Брайко Ю. О. [та ін.]. - Опубл. 10.05.2012. - Бюл. №9. 